\title{
The Tax Treatment of Intergenerational Wealth Transfers*
}

\author{
Helmuth Cremer $^{\dagger}$ and Pierre Pestieau \\ ${ }^{\dagger}$ Toulouse School of Economics (GREMAQ and IDEI), and Institut universitaire de France. \\ CREPP, University of Liège, and CORE, University of Louvain. \\ e-mail: p.pestieau@ulg.ac.be
}

\begin{abstract}
This article surveys the theoretical literature on wealth transfer taxation. The focus is normative: we are looking at the design of an optimal tax structure from the standpoint of both equity and efficiency. The gist of this survey is that the optimal design crucially depends on the assumed bequest motives. Alternative bequest motives are thus analyzed either in isolation or combined. (JEL codes: H21, H23, H24, E6, D64)
\end{abstract}

Keywords: Estate tax, inheritance tax, bequests, public finance

\section{Introduction}

Taxes are rarely popular but those on wealth transfers are particularly controversial. A number of countries such as Canada and Italy are without an inheritance or an estate tax and some contemplate to phase it out in the near future. Opponents of the 'death tax' as they have dubbed it claim that it is unfair and immoral. It adds to the pain suffered by mourning families and it prevents small business from passing from generation to generation. Because of many loopholes, people of equivalent wealth pay different amounts of tax depending on their acumen at tax avoidance. It hits families that were surprised by death (and it is therefore sometimes called a tax on sudden death). It penalizes the frugal and the loving parents who pass wealth on to their children, reducing incentive to save and to invest.

Supporters of the tax, in contrast, retort that it is of all taxes the most efficient and the most equitable. They assert that it is highly progressive and counterweight existing wealth concentration. They also argue that it has few disincentive effects since it is payable only at death and that it is fair since it concerns unearned resources. For a number of social philosophers and classical economists, estate or inheritance taxation is the ideal tax.

Clearly, death taxation more than any other generates controversy at all levels: political philosophy, economic theory, political debate, and public opinion. The truth probably lies between these two opposite camps.

* Paper presented at the CESIfo Venice Summer Institute Workshop on "Taxation and the Family", July 24-26, 2003. 
For economists this tax like all taxes should be judged against the two criteria of equity and efficiency to which one could add that of simplicity and compliance.

In this survey, ${ }^{1}$ we focus on the criteria of equity and efficiency. Equity is hard to gauge. It has inter- and intragenerational aspects that can only be measured by relying on some normative criterion. Efficiency implies minimizing distortions to economic activity with an important dynamic dimension. Inheritance taxes affect incentive governing the choice between consuming now and bequeathing. The gist of this survey is that inheritance taxation cannot be analyzed separately from other taxes and that its implications in terms of efficiency and equity depend on why people leave assets when they die.

As a benchmark, we consider a dynamic model without bequest and study the optimal structure of taxation in the absence of bequests. Assuming that taxes can be levied on saving and labor income and are distortive, we want to see how this tax structure is affected when bequests are introduced and can be taxed as well.

As it will appear, the resulting tax structure depends on the bequest model chosen. One model states that bequests are simply an accident. People do not know how long they will live and so they keep more money than they turn out to need. If bequests are accidental, estate taxation is quite efficient. However, if people are motivated to work and to save by the idea of leaving their families an inheritance, the tax will be distortionary. The impact of the distortion will depend on the bequest motive. If people have a specific amount they wish to leave to their children regardless of their needs and their behavior, the outcome will be different from what it would be if the amount bequeathed is determined by a concern for the welfare of the heirs.

The survey deliberately adopts a theoretical and normative view. ${ }^{2}$ It studies how transfers between generations ought to be taxed along with other tax tools and according to some welfare criterion. The type of tax that is thus obtained does not necessarily correspond to existing taxes.

To characterize the tax structure, one first has to distinguish taxation at death from taxation on inter vivos gifts which can have different rates. One also distinguishes three broad categories of death taxes. An estate tax is based on the total estate of the donor. An inheritance tax, on the other hand, is based on the share received by each donee and tax rate scales and thresholds depend on the relationship between the donor and the donee.

1 See also the recent survey by Boadway et al. (2010).

2 For an empirical survey, see Arrondel et al. (1997), Pestieau (2003) and Gale et al. (2000). This is not the first theoretical survey. See e.g. Batina and Ihori (2000), Erregeyers and Vandevelde (1997), Aaron and Munnell (1992), Kaplow (2000), Kopczuk (2001). 
Finally, the accession tax is based on the share received by the donee plus his other assets. One would hope that the theory will indicate which of these forms is the most desirable.

The rest of this article is organized as follows. Section 2 presents a brief overview of actual wealth transfer taxation and of alternative bequest models. Section 3 develops the optimal tax structure under alternative models. We proceed in steps. We first assume that individuals are identical but for age and generation and that the government can control the capital stock. Then we introduce restrictions to the ability of government of controlling aggregate saving and we consider individual heterogeneity. Section 4 looks at a number of theoretical issues regarding the choice between estate and inheritance taxation, differential taxation of bequests and inter vivos gifts, the coexistence of different bequest motives within the same society, the transmission of human capital and finally the non observability of inherited wealth.

\section{Institutions, taxes, and motives}

\subsection{Institutions and wealth transfer taxes}

The nature of wealth transfers is undoubtedly affected by the legal institutions that govern their transmission, and the potential economic effects depend directly on the motive for the transfer. Before considering some facts on wealth transfer taxation, let us look at alternative institutions and motives.

\subsubsection{Legal institution}

Political economy is a growing field that deals with the effect of institutions on policy outcomes. A considerable amount of work has been done linking budgetary institutions and budget deficits, fiscal federation, and the size of the government, electoral rules and fiscal policy, to take three well-known examples. In the same vein, it would be interesting to link the legal institution regulating bequest and the actual practice of gift and estate transfers.

Legal institutions vary greatly from country to country. With regard to the institutional setting for private wealth transfers, two important dimensions are the freedom of bequest and the taxation of transfers. Table 1 joins these two dimensions, showing how countries such as the USA and the UK can be contrasted with France and Germany. ${ }^{3}$

At death, two main types of taxes are levied on wealth transfers. The first is the estate tax, which is levied on the total estate of the donor,

3 Masson and Pestieau (1997). 
Table 1 Legal institutions regulating wealth transfers

\begin{tabular}{llll}
\hline & \multicolumn{3}{c}{ Taxation } \\
\cline { 2 - 4 } Freedom of bequest & None & Estate & Inheritance \\
\hline Absolute & Canada & USA, UK & - \\
$\begin{array}{l}\text { Restricted to children } \\
\text { and equal sharing }\end{array}$ & - & - & France, Germany \\
\hline
\end{tabular}

Source: Masson and Pestieau (1997).

regardless of the characteristics and the number of recipients. This tax is used both in the USA and in the UK. The second type is the inheritance tax levied on the share received by the recipient. Inheritance taxation typically includes a variety of rate scales and thresholds that depend on the relationship between donor and recipient. Most European countries, with the exception of the UK and to a lesser extend Italy, have inheritance taxation.

Table 2 provides some information on the structure of inheritance taxation in a number of European Union countries. Tax rates that are applied when wealth is transmitted to children or to strangers 'in blood' vary from country to country, as does the level of exemption. The taxes provide special treatment for spouses and charitable contributions. The final columns of Table 2 record the extent to which inter-vivos transfers are subject to the same treatment as bequests. Yet in reality, gifts are subject to much lower effective tax as they can benefit from substantial exemption for each child and each year.

In general, estate taxation gives one total freedom to bequeath one's wealth to anyone or anything. Disinheritance is possible, as long as the decedent prepares an explicit will. Inheritance taxation, on the other hand, often comes with the legal obligation to bequeath one's wealth to one's children, if any, and with an equal sharing of most of the estate. Donors have some freedom to do as they wish with a small fraction of the estate, but this fraction declines with the number of children. As the relation between recipient and donor gets more distant, the inheritance tax treatment becomes less and less generous.

The relative merits of the estate-type and the inheritance-type taxation are clear. The first is simple and relatively easy to administer, leaving all discretion to donors to dispose of their wealth as they wish. This means that it is possible to compensate some children over others for differences in income or need and that it is possible to disinherit one's children. In contrast, the inheritance tax is more equitable than the estate tax in that it 
Wealth Transfer Taxation

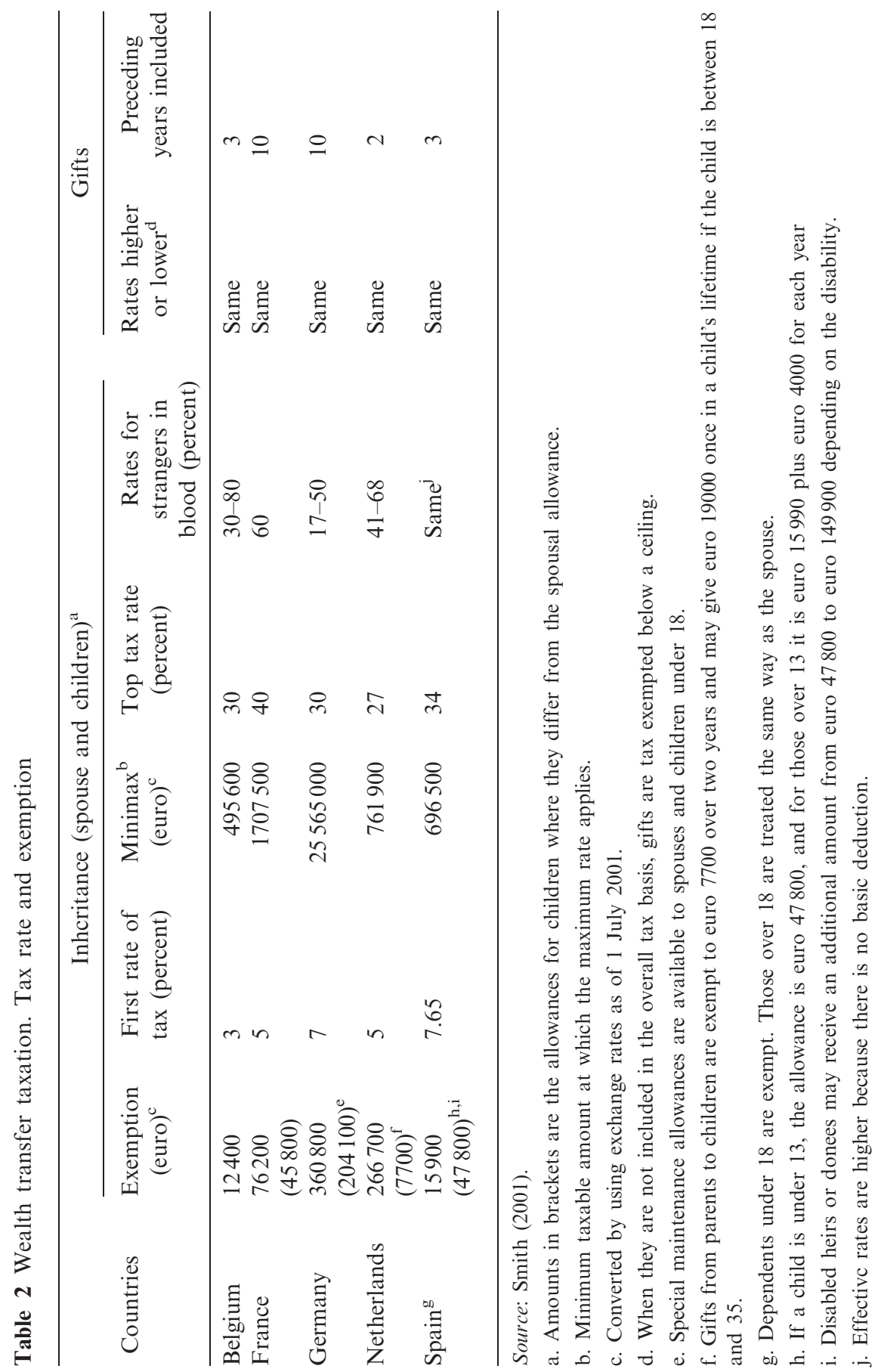


lightens the tax load of large families. Yet, it does not allow for compensatory treatment of children with uneven endowments. ${ }^{4}$

Basically, estate taxation reflects a concept of the family and of the state that is quite different from the one that governs inheritance taxation. If one trusts parents to be fair in disposing of their estate, and if one believes that intrafamily inequality is as important as interfamily inequality, then what is desirable is a combination of freedom of bequest and a very low estate tax.

On the other hand, if one does not trust parents to make compensatory transfers within the family, and wealth varies enormously across families, then high inheritance taxation with mandatory equal sharing seems to be the best solution. We come back on this in Section 4.1.

The regulation of estate division can have surprising implications. It has been shown that in agricultural France, equal sharing, unlike total freedom of bequeathing, has induced families to have fewer children. The traditional objective of parents in an agricultural environment has been to keep the estate from being divided. This was possible with primogeniture, but not with equal sharing. Therefore, the only choice left was to have one, or at most, two children. ${ }^{5}$ During the English Middle Ages, the frequency of remarriage, along with existing societal values, traditionally led to the mistreatment of stepchildren by stepparents. To prevent disinheritance, equal division was imposed. When both the demographic and the societal evolution made such situations less likely, England moved back to unrestricted bequeathing. In contrast, most of Continental Europe maintained restrictive equal sharing. ${ }^{6}$

\subsubsection{Importance of wealth transfer taxes}

Wealth transfer taxation is different in the USA from Continental Europe. Besides the difference analyzed above between estate and inheritance taxation, estate taxation in the USA is known to concern only the very wealthy households. Generally speaking, the deductible - the amount below which there is no taxation - is 10 times higher in the USA than in France and 50 times higher than in Belgium. Regardless of the type of wealth transfer taxation, the yield is uniformly low. Table 3 provides for a sample of OECD countries the relative yield of wealth taxation, which barely exceeds $1 \%$ of total revenue. In 2006 only Belgium, France, and Japan exceeded that level. Italy and Sweden have abolished their inheritance tax.

4 Cremer and Pestieau (1988) argue that tax rates that decrease with the degree of consanguinity can be redistributive.

5 Rosenthal (1991).

6 Brenner (1985). 
Table 3 Wealth transfer taxes as a percentage of total tax revenues, 1965-2006

\begin{tabular}{lcccccccccc}
\hline & 1965 & 1970 & 1975 & 1980 & 1985 & 1990 & 1995 & 2000 & 2005 & 2006 \\
\hline Belgium & 1.17 & 1.06 & 0.76 & 0.82 & 0.59 & 0.71 & 0.76 & 0.97 & 1.30 & 1.39 \\
Denmark & 0.65 & 0.36 & 0.38 & 0.44 & 0.47 & 0.56 & 0.47 & 0.45 & 0.40 & 0.43 \\
Germany & 0.22 & 0.23 & 0.14 & 0.18 & 0.22 & 0.34 & 0.26 & 0.39 & 0.53 & 0.46 \\
Ireland & 1.89 & 1.25 & 1.12 & 0.35 & 0.30 & 0.39 & 0.44 & 0.67 & 0.50 & 0.62 \\
Greece & 0.86 & 1.35 & 1.00 & 1.22 & 0.95 & 1.23 & 0.97 & 0.80 & 0.42 & 0.34 \\
Spain & 1.05 & 0.86 & 0.79 & 0.41 & 0.41 & 0.42 & 0.51 & 0.63 & 0.74 & 0.74 \\
France & 0.56 & 0.72 & 0.72 & 0.57 & 0.61 & 0.95 & 0.82 & 1.07 & 1.19 & 1.04 \\
Italy & 0.85 & 0.64 & 0.21 & 0.21 & 0.23 & 0.14 & 0.15 & 0.20 & 0.01 & 0.01 \\
Luxembourg & 0.38 & 0.48 & 0.32 & 0.32 & 0.27 & 0.29 & 0.27 & 0.27 & 0.39 & 0.39 \\
The Netherlands & 1.08 & 0.59 & 0.37 & 0.48 & 0.44 & 0.50 & 0.61 & 0.90 & 0.86 & 0.86 \\
Austria & 0.26 & 0.23 & 0.19 & 0.17 & 0.17 & 0.14 & 0.11 & 0.01 & 0.14 & 0.12 \\
Portugal & 2.02 & 1.47 & 0.86 & 0.22 & 0.83 & 0.50 & 0.21 & 0.25 & 0.08 & 0.01 \\
Finland & 0.22 & 0.24 & 0.21 & 0.22 & 0.27 & 0.37 & 0.38 & 0.59 & 0.70 & 0.70 \\
Sweden & 0.39 & 0.36 & 0.25 & 0.21 & 0.26 & 0.19 & 0.16 & 0.22 & 0.07 & 0.01 \\
UK & 2.62 & 2.01 & 0.82 & 0.59 & 0.69 & 0.65 & 0.58 & 0.62 & 0.70 & 0.74 \\
USA & 2.06 & 1.68 & 1.45 & 1.15 & 0.82 & 1.00 & 0.98 & 1.22 & 0.90 & 0.89 \\
Japan & 0.71 & 0.94 & 0.97 & 0.71 & 1.18 & 1.47 & 2.02 & 1.31 & 1.14 & 1.06 \\
& & & & & & & & & & \\
\hline
\end{tabular}

Estate. inheritance and gift taxes as a percentage of total taxation.

Source: OECD (2008), Revenue Statistics 1965-2006, Paris, OECD.

Over time, the evolution of estate, inheritance, and gift taxes has not been uniform. Figures 1 and 2 show stability in the USA and the USA, after a drastic decline for the latter in the early 1970s. In contrast, France has seen an increase with the arrival of the Left to the government in 1981. Japan and Spain are rather stable. Clearly, wealth taxes do not reduce reliance on other taxes. In some cases, e.g. France, inheritance taxes are imposed in conjunction with an annual wealth tax, but wealth tax yields are even lower that those of wealth transfer taxes. ${ }^{7}$

Table 3, even if it were made more complete, would not allow for a fair comparison of the wealth transfer tax system across countries. The top marginal rate in the French inheritance tax is lower that the top marginal tax rate in the USA estate and gift tax. However, the exempt amounts are much higher in the USA than in France. Besides, in the USA the tax base is the whole estate, whereas in France it is the amount received by each heir. Note also that in France, rates are substantially higher on 'strangers in blood', and the exemption much lower. Finally, in France, assets such

7 See Smith (2001) for more information. 


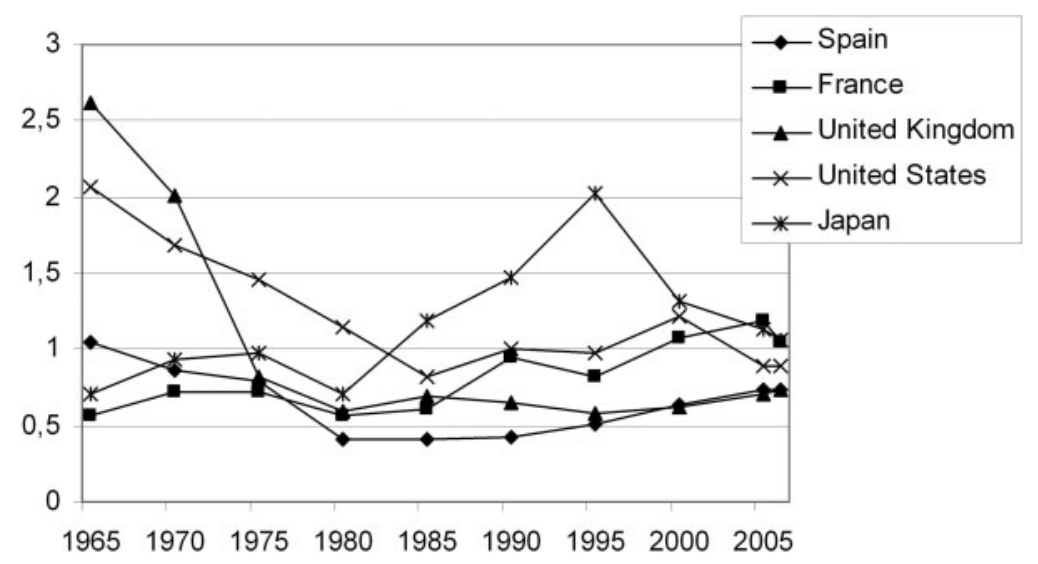

Figure 1 Wealth transfer taxes as \% of total tax revenues. Source: OECD (2008), Revenue Statistics 1965-2006, Paris, OECD.

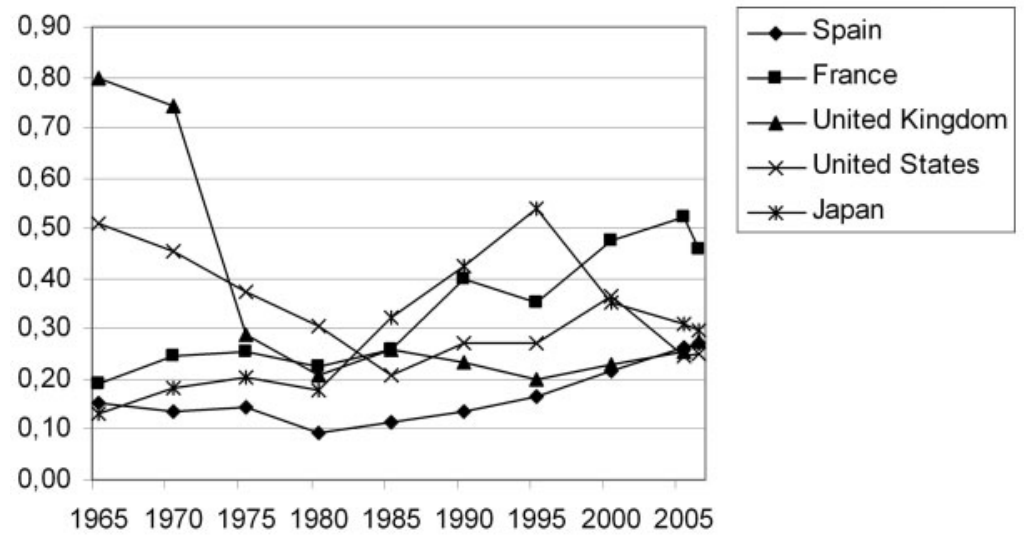

Figure 2 Wealth transfer taxes as \% of GDP. Source: Revenue Statistics of OECD member countries, Paris, OECD, 2008.

as agricultural and forestland, term life insurance benefits, and artwork donated to the government are exempted from inheritance taxation.

It would seem that in the balance between avoidance and evasion, Americans favor avoidance, and Europeans, evasion. This contrast raises an interesting question. Given that the death tax yield is the same in the USA and in Europe, is it better to elude its burden by giving away money to foundations or by investing it in tax havens such as Luxembourg or Switzerland? In addition to tax evasion, the European Union is engaged in an important race to the bottom regarding financial capital income 
taxation. This can have some effect on wealth transfer taxation, as has been the case in the USA with estate taxation. The difference is that the European Union does not have a supranational government to regulate such tax competition. For example, tax competition is invoked in Italy in favor of repealing the inheritance tax. In Belgium, the Flemish region has lower rates and higher exemptions that the rest of the country.

\subsection{Taxonomy of transfers motives}

It is now widely agreed that to understand the importance and the role of gifts and estate transfers one needs to have a better grasp of the donor's motives, if any. Consider two examples concerning gifts and bequests. First, when the transfer takes the form of gifts it may be unclear whether they are 'true gifts', due to altruism, or effectively involve some sort of exchange (the donee provides services to the donor). It is clear that a number of effects would differ under the two cases. Second, in the case of bequests we may not know whether they are left accidentally, because of the incompleteness of annuity markets, or intentionally for motives which rely on some type of altruism. Again, depending on the case, the effects of bequests on income inequality, capital accumulation, education could be quite different.

We examine briefly a number of bequest motives that have been offered in the literature and sketch their implications focusing on those that are testable. $^{8}$

\subsubsection{Pure dynastic altruism: altruistic bequest}

Parents care about the likely lifetime utility of their children and hence about the welfare of future generations. ${ }^{9}$

Accordingly, wealthier parents make larger bequests and holding parent's wealth constant children with higher labor earnings will receive smaller bequests. There is also a tendency for parents to leave different amounts to different children in order to equalize their incomes. Finally, pure altruism typically leads to the Ricardian equivalence: parents compensate any intergenerational redistribution by the government through matching bequests. In consequence, debt and pay-as-you go social security have no effect on capital accumulation.

8 See also on this Pestieau (2000), Cox (1987).

9 Among the classical references, one has Barro (1974), Becker and Tomes (1979, 1986). See also Altonji et al. (1992). 


\subsubsection{Joy of giving: paternalistic bequest (bequest-as-last-consumption)}

Parents here are motivated not by altruism but by the direct utility they receive from the act of giving. ${ }^{10}$ This phenomenon is also referred to as 'warm glow' giving. It can be explained by some internal feeling of virtue arising form sacrifice in helping one's children or by the desire of controlling their life. Formally these bequests appear in the utility function as a consumption expenditure incurred in the last period of life. Ceteris paribus, they are subject to income and price effects but do not have any compensatory effect, namely they are not intended to smoothen consumption across generations. A crucial element is whether what matters to the donor is the net or the gross of tax amount.

\subsubsection{Exchange-related motives: strategic bequests}

In their canonical form, exchange-related models consider children choosing a level of 'attention' to provide to their parents and parents remunerating them in the prospect of bequest. ${ }^{11}$ The exchanges can involve all sorts of non pecuniary services and they can be part of a strategic game between parents and children. Strategic bequests as they were originally presented imply that parents extract all the surplus from their children by playing them against each other.

Strategic or exchange bequests depend on the wealth and the needs of the donor; they are not compensatory between parents and children and they do not need to be equal across children.

\subsubsection{No bequest motive: accidental bequests}

Up to this point, we have considered planned bequests. Whatever the underlying motive they were voluntary. ${ }^{12}$ We now consider unplanned or accidental bequests which result from a traditional life-cycle model. Accordingly, people save during their working lives in order to finance consumption when retired. Bequests occur solely because wealth is held in bequeathable form due to imperfections in annuity markets or the need to have precautionary savings. The main implication of that form of bequests is that even a $100 \%$ estate tax rate should not have any disincentive effect on the amount of bequest.

In this survey, we will show that the tax structure depends crucially on the type of bequest motive considered. Table 4 gives an overview of some of the expected implications of wealth transfers for each of these

10 Andreoni (1990), Bevan and Stiglitz (1979), Glomm and Ravikunar (1992), Kotlikoff and Spivak (1981).

11 Bernheim et al. (1985), Cremer et al. (1993), Cremer and Pestieau (1991, 1996, 1998).

12 Davies (1981), Abel (1985). 
Table 4 Implications of bequests motives

\begin{tabular}{|c|c|c|c|c|}
\hline & \multicolumn{4}{|c|}{ Types of bequests } \\
\hline & Accidental & Altruistic & Paternalistic & Exchange \\
\hline \multicolumn{5}{|c|}{ Effect on intrafamily disparity } \\
\hline $\begin{array}{l}\text { Disparity between } \\
\text { parents and children }\end{array}$ & Neutral & Equalizing & Neutral & Neutral \\
\hline Disparity among siblings & Neutral & Equalizing & Neutral & Neutral \\
\hline Equal estate division & $\begin{array}{l}\text { Yes by } \\
\text { default }\end{array}$ & No & $\begin{array}{l}\text { Yes by } \\
\text { default }\end{array}$ & No \\
\hline Effect on social inequality & Uncertain & Positive & $\begin{array}{l}\text { Moderate but } \\
\text { positive }\end{array}$ & $\begin{array}{l}\text { Weak and } \\
\text { uncertain }\end{array}$ \\
\hline \multicolumn{5}{|l|}{ Effect of fiscal policy } \\
\hline $\begin{array}{l}\text { Public debt on } \\
\text { consumption }\end{array}$ & Positive & Neutral & Positive & Positive \\
\hline $\begin{array}{l}\text { Inheritance taxation } \\
\text { on saving }\end{array}$ & Nil & Negative & $\begin{array}{l}\text { Negative } \\
\text { or nil }\end{array}$ & Negative \\
\hline
\end{tabular}

alternative models. It summarizes the results of the existing literature on the subject. Concerning disparity between parents and children or among children, only altruistic bequests are expected to reduce them. The other types of bequests have other concerns. As to the division of estate both altruistic and strategic bequests are not supposed to follow the equal division solution that is adopted by default. Altruistic bequests are more generous for disadvantaged children and strategic bequests are higher for children providing the kind of attention parents particularly desire.

Contrary to what is often said, the effect of bequests on social inequality is rather uncertain. Only altruistic or paternalistic bequests ought to contribute to social immobility. Finally, as it is well known, altruistic bequests as long as they are operative lead to the Ricardian equivalence and any taxation of accidental bequest does not affect their amount.

To sum up, one clearly sees that there are two dividing lines. The first division is between pure altruism and the other motives; it concerns intraand intergenerational redistribution. The second is between unplanned and planned bequest, the former being indifferent to any restriction including taxation while the latter is affected by any obstacle to the freedom to bequeath.

\subsection{Canonical model}

We use a Diamond-style overlapping generation model. Identical individuals are assumed to live two periods, consuming in both, providing some 
labor in the first one. ${ }^{13}$ Population is increasing at the rate $n$. The government has an exogenously given revenue requirement which has to be financed. through taxes on income from labor and capital and on estate transfer, if any. Individual can derive some utility from transferring resources to their offsprings.

The problem of the representative consumer is to maximize his utility subject to the budget constraint.

$$
b_{t}+\omega_{t} \ell_{t}=c_{t}+\frac{d_{t+1}+x_{t+1}}{1+\varrho_{t+1}}
$$

where $b_{t}$ is inherited wealth, $x_{t+1}$ is the amount of bequests, $\omega_{t}$ is the consumer wage (net of tax), $\varrho_{t+1}$ the consumer rate of interest (after tax interest rate), $c_{t}$, first period consumption, $\ell_{t}$, labor supply and $d_{t+1}$, second period consumption. The preferences are represented by the following utility function:

$$
\begin{aligned}
u_{t} & =u\left(c_{t}, d_{t+1}, \ell_{t}\right)+\gamma B_{t+1} \\
& =u\left(c_{t}\right)+\beta u\left(d_{t+1}\right)-h\left(\ell_{t}\right)+\gamma B_{t+1}
\end{aligned}
$$

where $B_{t+1}$ is the utility derived from bequeathing if any, $\beta$ and $\gamma$ are positive parameters, $u(\cdot)$ is strictly concave and $h(\cdot)$ strictly convex. The additive specification is used for the sake of simplicity.

Consider now five models:

(1) No bequests: $\gamma=0, b=x=0$.

(2) Accidental bequests: $\gamma=0, \beta=\tilde{\beta} \theta$, where $\tilde{\beta}$ is the factor of time preference and $\theta$ is the survival probability. There is a probability $\theta$ that the individual will live till the end of the second period and $(1-\theta)$ that he will die at the end of the first period. In the latter case, $b_{t+1}=d_{t+1}$ / $(1+n)$ for a fraction $(1-\theta)$ of children whose parents decease prematurely.

(3) Paternalistic bequests: $B_{t+1}=h\left(x_{t+1}\right)$ and $b_{t+1}=x_{t+1} /(1+n)$.

(4) Altruistic bequests: $B_{t+1}=u_{t+1}$ and thus by recursion:

$$
u_{t}=\sum_{s=0}^{\infty} \gamma^{s} u_{s+t}
$$

with again $b_{t+1}=x_{t+1} /(1+n)$.

(5) Exchange-based bequests:

$$
B_{t+1}=h\left(a_{t+1}\right) \text { and } u_{t}=u\left(c_{t}-v\left(a_{t}^{g}\right), \ell_{t}, a_{t+1}\right)+\beta u\left(d_{t+1}\right)-h\left(\ell_{t}\right)
$$

13 Diamond (1965). 
where $a_{t+1}$ is attention received, $a_{t}^{g}$ is attention given representing a monetary cost of $v\left(a_{t}^{g}\right)$ that is paid by a bequest $b_{t}$. In the strategic bequest vein, we assume that $b_{t}=v\left(a_{t}^{g}\right)$.

We have three tax instruments: $\tau^{w}, \tau^{r}, \tau^{x}$, namely a proportional tax on earnings, interest income, inherited wealth. The government budget constraint is:

$$
\tau_{t}^{w} \ell_{t}+\frac{\tau_{t}^{r} s_{t-1}+\tau_{t}^{x} x_{t}}{1+n}=R
$$

where $R$ is the (per capita) revenue requirement, $w_{t}$ and $r_{t}\left(\omega_{t}\right.$ and $\left.\varrho_{t}\right)$ are the producer (consumer) factor prices $\left(\tau^{w}=w-\omega ; \tau^{r}=r-\varrho\right)$ and $s_{t-1}$ is saving.

\section{Optimal taxation of factor income and wealth transfer}

\subsection{The overlapping generation model}

In the Diamond (1965) model each generation lives for two periods, consuming in both and working in the first. There are no bequests and the lifetime budget constraint for the representative household born in period $t$ may be written:

$$
c_{t}+\frac{d_{t+1}}{1+\varrho_{t+1}}=\omega_{t} \ell_{t} .
$$

It is clear that endowing the government with two instruments, taxes on labor income $\left(\tau^{w}=w-\omega\right)$ and capital income $\left(\tau^{r}=r-\varrho\right)$ is equivalent to allowing the government to tax first- and second-period consumption at possibly different rates. A zero-tax on capital income - a labor income tax-would result in uniform taxation of consumption in the two periods. ${ }^{14}$

We now characterize the optimal steady-state taxes resulting from a utilitarian objective

$$
\sum \delta^{t} u_{t}
$$

where $0<\delta<1$ is the factor of social time preference and

$$
u_{t}=u\left(c_{t}, d_{t+1}, \ell_{t}\right)
$$

is the individual utility function. Two general results have been obtained. First with the government able to redistribute resources across generations

14 See Atkinson and Sandmo (1980), Pestieau (1974). 
through debt policy, pay-as-you-go social security or any other devices the marginal product of capital converges to the population growth rate divided by the factor of time preference $((1+n) / \delta)$, namely the modified golden rule. Second, optimal taxes on labor and capital should follow the standard analysis of static optimal tax theory.

Maximizing (5) subject to (1) yields the demand function for $c\left(\omega_{t}, \varrho_{t+1}\right)$, $d\left(\omega_{t}, \varrho_{t+1}\right)$ and $\ell\left(\omega_{t}, \varrho_{t+1}\right)$ which substituted back in the utility function yields the indirect utility function:

$$
v_{t}=v\left(\omega_{t}, \varrho_{t+1}\right),
$$

with

$$
\frac{\partial v_{t}}{\partial \omega_{t}}=\alpha_{t} \ell_{t} \text { and } \frac{\partial v_{t}}{\partial \varrho_{t+1}}=\frac{\alpha_{t} d_{t+1}}{\left(1+\varrho_{t+1}\right)^{2}}=\frac{\alpha_{t} s_{t}}{1+\varrho_{t+1}},
$$

where $\alpha$ is the marginal utility of income $\alpha=\partial u / \partial I$ and $s$ is saving. We use $I$ to denote non labor income, if any.

There is a production sector represented by a CRS production function relating output $Y_{t}$ to capital $K_{t}$ and labor $L_{t}$ :

$$
Y_{t}=F\left(K_{t}, L_{t}\right)
$$

or

$$
y_{t}=F\left(\frac{K_{t}}{L_{t}}, 1\right)=f\left(k_{t}\right)
$$

with $y=Y / L$ and $k=K / L$. With perfect competition factor payments equal the value of marginal products:

$$
w_{t}=F_{L}^{\prime}\left(K_{t}, L_{t}\right) \text { and } 1+r_{t}=F_{K}^{\prime}\left(K_{t}, L_{t}\right) .
$$

We assume total depreciation after one period and $L_{t}=\ell_{t} N_{t}$ where $N_{t}=N_{t-1}(1+n)$ is the size of generation $t$.

In this simple economy, the dynamics is conducted by the capital accumulation equation:

$$
K_{t+1}=N_{t} s_{t}
$$

where $s_{t}=\sigma\left(\omega_{t}, \varrho_{t+1}\right)=\omega_{t}-c\left(\omega_{t}, \varrho_{t+1}\right)$.

Under some assumptions, one can show that $k_{t+1}$ converges to a unique steady-state $k^{*}$ which can be compared to the steady-state value $\hat{k}_{\delta}$ which is consistent with the modified golden rule and defined by:

$$
f^{\prime}\left(\hat{k}_{\delta}\right)=\frac{1+n}{\delta} \text {. }
$$


For the time being we assume that the economy is on the modified golden rule growth path through some appropriate intergenerational transfers by the government. So doing we focus on the optimal tax structure abstracting from dynamic efficiency considerations.

The government's budget constraint is simply:

$$
\tau_{t}^{w} \ell_{t}+\tau_{t}^{r} \frac{d_{t}}{\left(1+\varrho_{t}\right)(1+n)}=R,
$$

where $R$ is given. The second term on the left is the revenue from capital income taxation which concerns the previous generation $\left(s_{t-1}=d_{t}\right)$ $\left.\left(1+\varrho_{t}\right)\right)$.

We solve this problem by differentiating the Lagrangean expression,

$$
\mathcal{L}=\sum \delta^{t}\left\{v\left(\omega_{t}, \varrho_{t+1}\right)+\mu\left(\tau_{t}^{w} \ell_{t}\left(\omega_{t}, \varrho_{t+1}\right)+\tau_{t}^{r} \frac{d_{t}\left(\omega_{t-1}, \varrho_{t}\right)}{\left(1+\varrho_{t}\right)(1+n)}-R\right)\right\},
$$

with respect to $\omega_{t}$ and $\varrho_{t}$. This yields:

$$
\begin{gathered}
\frac{\partial \mathcal{L}}{\partial \omega_{t}}=\delta^{t}\left(\alpha_{t} \ell_{t}+\mu\left[\tau_{t}^{w} \frac{\partial \ell_{t}}{\partial \omega_{t}}-\ell_{t}+\tau_{t}^{r} \frac{\partial d_{t+1}}{\partial \omega_{t}} \frac{\delta}{(1+n)\left(1+\varrho_{t+1}\right)}\right]\right) \\
\frac{\partial \mathcal{L}}{\partial \varrho_{t+1}}=\delta^{t}\left(\alpha_{t} \frac{d_{t+1}}{\left(1+\varrho_{t+1}\right)^{2}}+\mu\left[\tau_{t}^{w} \frac{\partial \ell_{t}}{\partial \varrho_{t+1}}+\frac{\delta}{1+n}\right.\right. \\
\left.\left.\left(\tau_{t+1}^{r} \frac{\partial d_{t+1}}{\partial \varrho_{t+1}} \frac{1}{1+\varrho_{t}}-\frac{d_{t+1}\left(1+r_{t+1}\right)}{\left(1+\varrho_{t}\right)^{2}}\right)\right]\right) .
\end{gathered}
$$

Evaluating (7) and (8) in the steady-state, while adding and subtracting the income effect times $\ell$ for $\partial \mathcal{L} / \partial \omega$ and times $d /(1+\varrho)^{2}$ for $\partial \mathcal{L} / \partial \varrho$ yields:

$$
\begin{array}{r}
\left(\frac{\alpha}{\mu}-1-\Delta\right) \ell+\tau^{w} \frac{\partial \tilde{\ell}}{\partial \omega}+\tau^{r} \frac{\partial \tilde{d}}{\partial \omega} \frac{\delta}{(1+n)(1+\varrho)}=0 \\
\left(\frac{\alpha}{\mu}-1-\Delta\right) \frac{d}{(1+\varrho)^{2}}-\frac{1+n-\delta(1+r)}{1+n} \frac{d}{\left(1+\varrho_{t}\right)^{2}} \\
+\tau^{w} \frac{\partial \tilde{\ell}}{\partial \varrho}+\tau^{r} \frac{\partial \tilde{d}}{\partial \varrho} \frac{\delta}{(1+n)(1+\varrho)}=0
\end{array}
$$

where

$$
\Delta=\tau^{w} \frac{\partial \ell}{\partial I}+\tau^{r} \frac{\partial d}{\partial I} \frac{\delta}{(1+n)(1+\varrho)},
$$


and the ${ }^{\sim}$ denotes the compensated effects. Given our assumption on the modified golden rule, this can be further simplified:

$$
\tau^{w} \frac{\partial \tilde{\ell}}{\partial \omega}+\tau^{r} \frac{\partial \tilde{d}}{\partial \omega} \frac{\delta}{(1+n)(1+\varrho)}=\left(\tau^{w} \frac{\partial \tilde{\ell}}{\partial \varrho}+\tau^{r} \frac{\partial \tilde{d}}{\partial \varrho} \frac{\delta}{(1+n)(1+\varrho)}\right) \frac{\ell(1+\varrho)^{2}}{d} .
$$

This equation characterizes the relative levels of the tax rates on earnings and capital income with the absolute levels being determined by the government's revenue requirement $R$. As usual this characterization depends on compensated and not gross derivatives. Assume for simplicity of interpretation that the cross effects are zero. Then we can have:

$$
\frac{\tau^{w} / \omega}{\tau^{r} / \varrho}=\frac{\tilde{\varepsilon}_{d \varrho}}{\tilde{\varepsilon}_{\ell w}} \frac{1+\varrho}{\varrho(1+r)}
$$

where the $\tilde{\varepsilon}$ are the compensated elasticities. If labor is completely inelastic along the compensated supply curve, the optimal tax on interest income is zero because the tax on earnings is equivalent to a lump-sum tax. The argument is reversed when the demand for future consumption is inelastic. In general, however, there is no particular reason to believe that either tax will be zero nor that both taxes are the same.

Let us come back to the assumption that the economy is on the modified golden rule path, that is, on the assumption that the government can control capital. From (10) one can see that if $1+n \neq(1+r) \delta$ we have an additional term in either (11) or (12). In other words these taxes are not only used to finance $R$ but also to foster or discourage capital accumulation depending on whether the rate of interest is higher or lower than the rate of population growth divided by the discount factor.

As shown by Atkinson and Sandmo (1980) too little capital may call for a lower taxation of earnings and a higher tax on interest income than when the modified golden rule holds. This apparent paradox can be explained by noting that with a log-linear utility function saving depends only on earnings and not on the interest rate. ${ }^{15}$

We shall now introduce transfers into this model and successively consider the motives discussed in Section 2.2. Within each setting we study the design of factor income and wealth transfer taxes. To do so it is convenient to distinguish the case where the government has the instruments to secure the modified golden rule from the case where the government cannot fully control the capital stock.

15 Naturally, their argument applies also to other utility functions. 


\subsection{Accidental bequest}

The accidental bequest case is not much different from the case without bequest. Saving is affected by survival probabilities. Accidental transfers are taxed at $100 \%$, without affecting the supply of saving. The part of public spending (if any) which exceeds the proceeds of the transfer tax is financed through labor and capital income taxes designed à la AtkinsonSandmo.

\subsection{Pure altruism}

To keep things relatively simple, we assume that $\beta=0$ so that $d=0$. In other words, people live only one period and only save for bequeathing. ${ }^{16}$ This assumption implies that the tax on saving is also the tax on wealth transfer. ${ }^{17}$ Then, the social planner's problem at time 0 is to maximize:

$$
\sum_{t=0}^{\infty} \gamma^{t} u\left(c_{t}, \ell_{t}\right)
$$

subject to the resource constraint

$$
F\left(k_{t}, \ell_{t}\right)=(1+n) k_{t+1}+c_{t}+R,
$$

and to the revenue constraint

$$
(1+n) z_{t+1}=\left(1+\varrho_{t}\right) z_{t}+\left(1+\varrho_{t}\right) k_{t}+\omega_{t} \ell_{t}-F\left(k_{t}, \ell_{t}\right)+R,
$$

where $z$ denotes per worker public debt. Recall that $k$ is the per worker capital stock while $R$ per worker public spending and that the production function exhibits constant returns to scale.

Chamley (1986), Judd (1985) and Coleman (2000) show the following:

- if one could tax as much as possible initial wealth $k_{0}$, one could do without using any distortionary tax;

- if this first-best solution is not accessible, one will have initially a tax on both earnings and saving (that is bequests); and

- in the long run the tax on saving tends to 0 .

We restrict ourselves to proving the last point which represents the main result. The government's objective is the same as that of the representative

16 The classical papers on this are Chamley (1986) and Judd (1985).

17 We have the following equality between saving and bequest:

$$
s_{t}=x_{t+1}=(1+n) k_{t+1} \text {. }
$$


individual $(\gamma=\delta)$. It maximizes the Lagrangean:

$$
\begin{aligned}
\mathcal{L}= & \sum_{t=0}^{\infty} \gamma^{t}\left[u\left(c_{t}, \ell_{t}\right)+\lambda_{t}\left(F\left(k_{t}, \ell_{t}\right)-c_{t}-(1+n) k_{t+1}-R\right)\right] \\
& +\mu_{t}\left[(1+n) z_{t+1}-\left(1+\varrho_{t}\right) z_{t}-\left(1+\varrho_{t}\right) k_{t}-\omega_{t} \ell_{t}+F\left(k_{t}, \ell_{t}\right)-R\right],
\end{aligned}
$$

where $\lambda$ and $\mu$ are the Lagrange multiplier associated with the resource and the revenue constraint, respectively. The FOC with respect to $z$ and $k$ in the steady-state are:

$$
(1+\varrho) \gamma=1+n
$$

and

$$
-(1+n) \lambda+\gamma \lambda(1+r)+\mu \gamma(r-\varrho)=0 .
$$

Combining these two equations give:

$$
-\lambda(1+\varrho)+\lambda(1+r)+\mu(r-\varrho)=0 .
$$

This yields $(\lambda+\mu)(r-\varrho)=0$ and thus $\tau^{r}=0$, so that (13) implies $(1+r)$ $\gamma=1+n$. In words, we have the modified golden rule and most notably, a zero tax on savings which correspond to bequests in our setting. Consequently, wealth transfers are not taxed in the steady state. ${ }^{18}$

Chamley-Judd's result has become the standard rule for a number of public economists and particularly macroeconomists. However, it has also been challenged on various grounds. It relies on a set of strong assumption which have been questioned. In any case the zero tax result only applies to the steady-state; during the transition period, wealth transfers along with capital income are subject to taxation.

In a recent paper, Saez (2002) introduces a progressive tax on capital income (instead of a linear one) in the Chamley-Judd model. Under some plausible assumption, he shows that such a tax is desirable; it drives all the large fortunes down a finite level and produces a truncated long-run wealth distribution.

\subsection{Joy of giving}

Unlike in the case of pure altruism, the objective of individuals and that of the social planner may now diverge. Each individual maximizes:

$$
u\left(c_{t}, d_{t+1}, \ell_{t}\right)+\gamma v\left(x_{t+1}\right),
$$
18 This result generalizes to the case where $\beta>0$ and $d>0$. However, the proof becomes
much more complicated. 
subject to

$$
x_{t}+\omega_{t} \ell_{t}=c_{t}+\frac{d_{t+1}+(1+n)\left(1+\tau^{x}\right) x_{t+1}}{1+\varrho_{t+1}} .
$$

In a laissez-faire equilibrium, each individual chooses $\ell_{t}, c_{t}, d_{t+1}$ and $x_{t+1}$ given factor prices $\omega_{t}$ and $\varrho_{t}$ and inherited wealth $x_{t}$. As to the social optimum, one faces the issue of whether or not laundering individual utilities. Harsanyi (1995) and Hammond (1988) have advocated 'excluding all external preferences, even benevolent ones, from our social utility function'. Advocates of a utilitarian approach, on the other hand, argue that the social planner cannot paternalistically modify individuals' preferences.

We shall use a generalized objective which admits the two approaches as special case. Denoting the social factor of time preference by $\delta$, social welfare is given by

$$
U_{t}=\sum_{s=1}^{\infty} \delta^{s}\left[u\left(c_{s}, d_{s+1}, \ell_{s}\right)+\varepsilon \gamma v\left(x_{s+1}\right)\right],
$$

where $0 \leq \varepsilon \leq 1$ with $\varepsilon=0$ for the non utilitarian and $\varepsilon=1$ for the utilitarian case.

With this setting, the steady-state rule of optimal capital accumulation is the modified golden rule. The key issue is the treatment of $x_{t}$. For $\varepsilon=1$ the first-best optimal value of $x$ is that for which $v^{\prime}(x)=0$. In other words without laundering out utilities the social planner will push for a very high value of $x$ (that could be infinity). In a first-best world, such a solution could be implemented through a subsidy on $x$ financed by public debt. It is clearly not reasonable and such a pathological outcome provides an argument in favor of laundering out the joy of giving from the donors' welfare.

In the second-best, with linear taxes on earnings, capital income and bequests, the revenue constraint is given by:

$$
R=\tau_{t}^{w} \ell_{t}+\tau_{t}^{r} s_{t-1}+\tau_{t}^{x}(1+n) x_{t},
$$

which can also be written as:

$$
R=\tau_{t}^{w} \ell_{t}+\tau_{t} \frac{d_{t}}{1+\ell_{t}}+\theta_{t}^{x}(1+n) x_{t},
$$

where

$$
\theta_{t}^{x}=\frac{\tau_{t}^{r}\left(1+\tau_{t}^{x}\right)}{1+\varrho_{t}}+\tau_{t}^{x}
$$

is the total (or effective) tax on transfers. Observe that bequests are subject to a double tax: first, the tax on savings, $\tau^{r}$, and then the specific tax on 
transfers $\tau^{x}$. The total tax on bequest is higher than that on second period consumption if $\theta^{x}>\tau^{r} /\left(1+\varrho_{t}\right)$, which occurs when $\tau^{x}>0$.

Michel and Pestieau (2002) show that with no laundering the tax structure is not much different from (11). Taxes on earnings, on second period consumption and on bequests only depend on compensated elasticities and on the revenue requirement when the capital stock is directly controlled. In the case of zero cross elasticities, the tax on second period consumption $\left(\tau^{r}\right)$ may be higher than the estate tax $\left(\theta^{x}\right)$ if the own compensated elasticity of second period consumption is lower than that of bequests. When there is laundering, bequest loses its direct social utility and is thus subject to a relatively higher tax.

\subsection{Exchange}

We will use an exchange model of the strategic type in which parents obtain attention from their children in exchange of some bequests. By playing their children against each other they control the exchange to their full benefit. ${ }^{19}$

The utility function of an individual belonging to generation $t$ is given by:

$$
u\left(c_{t}-v\left(a_{t}^{g}\right), d_{t+1}, \ell_{t}, a_{t+1}\right),
$$

where $a_{t+1}$ denotes attention received and $a_{t}^{g}$ attention given which requires some effort. The disutility of attention given is expressed in monetary terms. First and second period budget constraints are:

$$
\begin{gathered}
\omega_{t} \ell_{t}+b_{t}=c_{t}+s_{t}, \\
\left(1+\varrho_{t+1}\right) s_{t}=\left(1+\tau_{t+1}^{x}\right) x_{t+1}+d_{t+1} .
\end{gathered}
$$

In addition, we have

$$
x_{t+1}=(1+n) b_{t+1}
$$

and

$$
v\left(a_{t}^{g}\right)=b_{t}
$$

Equation (18) gives the straightforward relation between bequest and inherited wealth. Equation (19) results from our strategic bequest assumption: parents extract all the surplus from their children who are just paid for the disutility of their effort.

\footnotetext{
19 We exclude collusion between children whereby they would agree to supply a minimal amount of attention and share the inheritance; see Cigno (1991).
} 
Substituting (16)-(19) into (15) shows that each member of generation $t$ maximizes the following expression

$$
u\left(\omega_{t} \ell_{t}-\frac{\left(d_{t+1}\right)}{1+\varrho_{t+1}}-\frac{v\left(a_{t+1}\right)\left(1-\tau_{t+1}^{x}\right)}{1+\varrho_{t+1}}, d_{t+1}, \ell_{t}, a_{t+1}\right) .
$$

The indirect utility is given by:

$$
V_{t}=V\left(\omega_{t}, \varrho_{t+1}, \tau_{t+1}^{x}\right) .
$$

The problem for the social planner is to maximize the discounted sum of utilities, $\sum \delta^{t} V_{t}$, subject to the revenue constraint:

$$
R=\tau^{w} \ell+\frac{\tau^{r} d_{t}}{\left(1+\varrho_{t}\right)(1+n)}+\frac{\tau_{t}^{r}+\tau_{t}^{x}\left(1+r_{t}\right)}{\left(1+\varrho_{t}\right)(1+n)} v\left(a_{t}\right) .
$$

We continue to assume that capital accumulation is socially optimal (i.e., $1+r=(1+n) / \delta)$. The FOC in the steady-state can be written as:

$$
\begin{aligned}
& \tau^{w} \frac{\partial \tilde{\ell}}{\partial \tau^{w}}+\frac{\tau^{r}}{(1+r)(1+\varrho)} \frac{\partial \tilde{d}}{\partial \tau^{w}}+\frac{\tau^{r}+\tau^{x}(1+r)}{(1+r)(1+\varrho)} v^{\prime}(a) \frac{\partial \tilde{a}}{\partial \tau^{w}}+\left(\frac{\alpha}{\mu}-1-\Delta\right) \ell=0 \\
& \tau^{w} \frac{\partial \tilde{\ell}}{\partial \tau^{r}}+\frac{\tau^{r}}{(1+r)(1+\varrho)} \frac{\partial \tilde{d}}{\partial \tau^{r}}+\frac{\tau^{r}+\tau^{x}(1+r)}{(1+r)(1+\varrho)} v^{\prime}(a) \frac{\partial \tilde{a}}{\partial \tau^{r}}+\left(\frac{\alpha}{\mu}-1-\Delta\right) \frac{d}{(1+\varrho)^{2}}=0 \\
& \tau^{w} \frac{\partial \tilde{\ell}}{\partial \tau^{x}}+\frac{\tau^{r}}{(1+r)(1+\varrho)} \frac{\partial \tilde{d}}{\partial \tau^{x}}+\frac{\tau^{r}+\tau^{x}(1+r)}{(1+r)(1+\varrho)} v^{\prime}(a) \frac{\partial \tilde{a}}{\partial \tau^{x}}+\left(\frac{\alpha}{\mu}-1-\Delta\right) \frac{v(a)}{1+\varrho}=0
\end{aligned}
$$

For same reasons as developed above (subsection 3.4), the overall tax on bequests, $\tau^{r}+\tau^{x}(1+r)$, may or may not be higher than that on future consumption. In other words, there is no particular reason to believe that the wealth transfer $\operatorname{tax} \tau^{x}$ is positive. This will depend on the relative magnitude of the compensated derivatives which determine the overall tax on bequests and the tax on future consumption through Atkinson and Sandmo type rules.

To illustrate this point in the simplest possible way, assume again that the cross elasticities are zero. Then, we have:

$$
\frac{\tau^{r}+\tau^{x}(1+r)}{\tau^{r}}=\frac{v(a) \frac{\partial \tilde{d}}{\partial \tau^{r}}(1+\varrho)}{v^{\prime}(a) \frac{\partial \tilde{a}}{\partial \tau^{x}} d} .
$$

Clearly if the demand for attention is much more elastic than that for future consumption, the tax on inheritance, $\tau^{x}$, is negative. 


\subsection{Inequality and wealth transfer taxation}

Up to now most of the discussion has focused on the restricted case of a representative individual and of full control of capital by the social planner.

On the latter issue, we have to note that with pure altruism and equality between the individuals rate of altruism and the social planner's time preference factor, the modified golden rule is achieved without the government intervening. With the other bequest motives there is no guarantee that the optimal accumulation of capital is achieved. Then if the government does not have direct control of capital, it has to use tax policy to affect the capital labor ratio. As already alluded to, if there is a need of additional capital accumulation, because $(1+r) \gamma>(1+n)$, this will not necessarily push for less taxation of capital income and wealth transfer and more taxation of labor income. What matters is aggregate saving and with a log-linear function saving depends on net of tax earnings relatively more than on the rate of interest.

Let us now consider individuals who differ in ability but have the same utility function. As shown by Atkinson and Stiglitz $(1972,1976)^{20}$ in the presence of weak separability between consumption and leisure, there is no need of taxation of capital within the standard OLG model. The Atkinson-Stiglitz theorem assumes that all households have identical utility functions and differ in their wage rates reflecting abilities or productivities, the government maximizes a quasi-concave (welfarist) objective function, applies a non linear income tax and could also apply linear excise taxes. Thus if the utility function is weakly separable in goods and labor so that $u(c, d, \ell)=u(g(c, d), \ell)$ a tax on capital income (alternatively on $d$ ) should not be used. Diamond (2006) [see also Banks and Diamond (2010)] discusses the robustness of the Atkinson-Stiglitz proposition. He shows a number of cases in which it does not hold and in which a taxation of capital income can be socially desirable. This occurs when the time discount factor is not observable and correlated with productivity, or when some initial endowment is private knowledge and correlated with productivity. There is also the setting in which individuals work in the second period and their productivity is unknown. This setting has been widely used by the so-called 'New Dynamic Public Finance' (see, e.g., Golossov et al. (2006)). All this work that revisits the Atkinson-Stiglitz proposition leads to the conclusion that the case for a zero taxation on capital income is rather weak.

With all these reservations, the Atkinson-Stiglitz result can be readily extended to the model with exchange (strategic bequest), granted that the 
government controls the rate of capital accumulation. ${ }^{21}$ Naturally if the economy does not converge to the modified golden rule, then the result does not hold anymore: capital income and wealth transfers will be taxed or subsidized depending on their effect on aggregate saving. ${ }^{22}$

The reason why the Atkinson and Stiglitz proposition applies to the strategic bequest model presented above is that bequest has no effect on the next generation. Each individual regardless of his ability and of his generation receives from his parents exactly what he pays for.

Individual heterogeneity does make a difference in the case of 'joy of giving'. The reason is rather simple. Even though the donor is not interested by the impact of his gift on the next generation's welfare the social planner cannot ignore this incidence. A non-linear income tax on generation $t$ does not make redundant a linear or a non-linear tax on what we can call a distributive externality.

The difficulty is how to express this externality, how to represent the effect of paternalistic gifts on the next generation's welfare. A convenient shortcut is to reduce individual heterogeneity to two levels of productivity, low and high, with endogenous probability. Suppose that the level of bequest has the effect of increasing the probability that the child's receiving it has a higher productivity. In other words, we assume that inherited wealth has the sole effect of fostering heirs' earning capacity. ${ }^{23}$ With such a specification we can show that with an optimal non-linear income tax it makes sense to have a tax or a subsidy on bequest. If there is no laundering out, a subsidy is desirable: fostering bequests implies increasing the probability of being more productive and thus the average level of human capital.

In case of laundering out the social planner may want to tax bequests as the joy of giving per se has no social value. We then have two opposite forces: one in favor of subsidizing bequests because of their positive externality on human capital and the other in favor of taxing bequests because they have no direct value for the social planner.

Note that the role of the tax-subsidy is not to redistribute income but to correct for some positive or negative externalities. In that respect it does not invalidate the Atkinson and Stiglitz proposition.

\footnotetext{
21 It is paradoxical that with a single individual the zero taxation of capital income does not apply with weak separability (you need strong separability à la Stone-Geary) and it does with heterogeneous individuals and optimal non-linear tax. The reason is that the equivalent of a non-linear income tax in a one-individual setting is the lump-sum tax (which is ruled out); see Atkinson and Stiglitz (1980).

22 The extension of the Atkinson and Stiglitz proposition to estate taxation has been discussed by Kaplow (2000) and Kopczuk (2001).

23 We use the argument given by Cremer and Pestieau (2001).
} 
Table 5 Alternative bequest motives

\begin{tabular}{lccc}
\hline & $\begin{array}{c}\text { With control of } \\
\text { capital and a } \\
\text { representative } \\
\text { agent }\end{array}$ & $\begin{array}{c}\text { Without control } \\
\text { of capital and a } \\
\text { representative } \\
\text { agent }\end{array}$ & $\begin{array}{c}\text { With control of } \\
\text { capital and heter- } \\
\text { ogenous agents } \\
\text { but with a non } \\
\text { linear income tax }\end{array}$ \\
\hline $\begin{array}{l}\text { Accidental bequest } \\
\text { Joy of giving }\end{array}$ & 1 & 1 & $<1$ \\
$\begin{array}{l}\text { Pure altruism } \\
\text { Exchange }\end{array}$ & 0 & \pm & \pm \\
& \pm & 0 & 0 \\
\hline
\end{tabular}

Let us now turn to the remaining bequest motives. In the model with pure altruism, the zero capital income tax result holds with different individuals without further assumptions. See on this Chamley (1986).

With accidental bequest, on the other hand, heterogeneity of individuals makes a difference. Indeed one can argue that under some conditions it is not anymore desirable to have a $100 \%$ tax on accidental bequests. Blumkin and Sadka (2004) show that a 100\% estate tax can interfere with the redistributing role of labor income taxation. This is the case when individuals with higher ability tend to spend a lower fraction of their marginal wealth on leisure than individuals with lower ability. As a result estate taxation would result in a reduction in aggregate labor earnings. Kopczuk (2003) correctly points out that accidental bequests result from some imperfections in the annuity markets and the first-best solution is not necessarily to tax them but rather to eliminate them.

Table 5 presents the main results obtained so far. Note that one cannot sign the tax on wealth transfer with joy of giving and with exchange regardless of whether or not the government controls capital.

With individuals differing in ability but with non-linear income tax, the Atkinson-Stiglitz result applies to the cases of joy of giving and exchange. The Atkinson-Stiglitz theorem assumes that the government can use a wide range of instruments. The literature contains a number of models exploring the consequences of restricting the policy environment.

For example, for administrative reasons, one can assume that the government cannot use non-linear tax schedules. If it is restricted to using linear income taxes, the case for a zero tax on capital income and wealth transfers (with accidental and exchange based bequests) is weakened. Another line of concern is that the government may very well observe labor earnings but not bequests. In that case, on which we come back below, a linear tax on capital income might be desirable; see subsection 4.4 . 
There is clearly the possibility that the government cannot control capital accumulation by debt policy. Then the Atkinson-Stiglitz proposition does not apply. While it may remain true that taxes on savings and bequests have not redistributive role, they may be useful for other reasons (e.g., to foster or limit capital accumulation). Also these taxes can be used when there is a conflict between individual and social preferences as it is the case when the social planner decides to launder the offspring's welfare out of parents' welfare.

Choosing between the two canonical models, the infinite lived individuals model and the OLG model and even more between their implications is not obvious. Both have in common to tell little about the nature of optimal tax schedules in transition. Except through numerical simulation (see e.g. Coleman 2000) we know little about the linkage between transition and long run policy. Chamley's model and his finding of a zero tax on capital income in the long run is striking and powerful. It quickly attracted a majority of economists concerned by the highly distortionary nature of such a tax. It however rests on the implausible assumption that agents live forever or behave in an equivalent manner with respect to their heirs. Without infinite lifetime no such result holds. This does not necessarily mean that a positive tax on capital income and on wealth transfer is the rule. We have seen that we could also have a subsidy. Note that the sign of the tax then depends on a number of factors including the revenue requirement and whether or not there is under-accumulation.

\section{Miscellaneous issues}

\subsection{Estate taxation or inheritance taxation}

As we have seen above, there exists two main types of wealth transfer taxes: ${ }^{24}$ the estate and the inheritance taxes which correspond to two contrasting views of inheritance.

For an economist, it would be interesting to see which of these two taxes correspond best to an optimal tax. In a first-best perfect information setting wealth transfer taxes can be designed along with the other taxes to achieve optimal redistribution within and across families. In an asymmetric information setting, this is less clear.

In a recent paper, Cremer and Pestieau (2001) adopt a second-best setting in which families are better informed than the tax authorities. ${ }^{25}$ Well to do families can be induced to leave lower bequests to avoid a too

\footnotetext{
24 The accession tax is another type but that has never been applied in any country.

25 Tax authorities observe the transfer to each of the children, but do not observe parent's wealth and children's ability.
} 
heavy tax burden. The paper studies the optimal design of a possibly non-linear wealth transfer tax. This problem encompasses the joint determination of the tax rates, the tax base and the sharing rules. In particular, sharing restrictions can be implemented through non-linearities in the tax function. $^{26}$

Basically it appears that the optimal tax is different from existing tax regimes. When the social planner and the parents weight the children in the same way, an estate tax, that is a tax based on aggregate bequest suffices. When they adopt different weights, then one needs to use a progressive tax formula that depends on individual bequests. In other words, we have something which resembles the inheritance tax but without compulsory equal sharing. Finally, when there is a possibility of the parent disinheriting their less endowed child, the government may find it optimal to impose a tax schedule which implies equal sharing along with a progressive tax.

\subsection{Inter vivos gifts versus bequests}

In most countries inter vivos gifts are subject to lower tax rates than bequests. Furthermore, gifts being made informally and in several installments they lend themselves to tax avoidance and tax evasion more easily than bequests. Also, in countries with inheritance taxation and mandatory equal sharing gifts are viewed as the only way to treat children differently according to needs, talents, or preferences.

From a theoretical viewpoint one can ask whether differential taxation of gifts and bequests is consistent with social optimality. There are some reasons which plead in favor of such a policy.

(i) Assume that the bulk of bequests is of accidental nature and that planned transfers are made much before the donor's death as inter vivos gifts. Then it makes much sense to discriminate in favor of inter vivos gifts.

(ii) Such a differential tax treatment fosters inter vivos gifts which are a more effective form of transfer in the case where heirs are liquidity constrained.

(iii) In countries where it applies, gifts cannot be subject to the same strict equal sharing rule as bequests. Therefore, they hopefully can be used for compensating for difference in luck or in talent among children. For that reason they ought to benefit from tax breaks.

26 Another issue is that of differential tor treatment depending on the relation between the donor and the donee. Typically rates are higher for strangers than for children. See Cremer and Pestieau (1988). 
However, there are also arguments against a heavier taxation of bequests. In particular, Cremer and Pestieau (1996, 1998) have shown that bequests as opposed to gifts can be used to induce children to reveal their ability and to provide a desirable amount of effort, which they would not do if they were given outside resources too early in their lifetime. In that respect, a tax break for inter vivos gifts is not necessarily desirable.

\subsection{Mixed motives}

The theoretical literature on wealth transfer taxation tends to assume that individual have only one type of bequest motives. The purpose of this section is to suggest that such an approach is deficient and it proposes to consider a society consisting of individuals with different motives. We first turn to a society consisting of individuals who combine different motives, namely who leave both altruistic and accidental bequests. Then we consider a society where individuals are all either altruistic or pure 'life-cyclers'.

\subsubsection{A mix of accidental and paternalistic bequest ${ }^{27}$}

It is widely believed that actual bequests are an hybrid of canonical types analyzed above and in particular of accidental bequests (related to imperfect annuity markets) and of paternalistic bequests (related to some joy of giving). In such a case, the estate consists of two components: an amount intended by altruistic parents and an amount which results from the 'premature' death of parents and which represents intended second period consumption in one overlapping generations framework. We have seen that these two types of bequests have totally different implications. Determining the relative importance of the time is thus crucial to design an optimal estate tax.

To illustrate this, we use an isoelastic utility function:

$$
u(c, d, x)=\left(c^{1-1 / \sigma}+\beta \theta d^{1-1 / \sigma}+\gamma x^{1-1 / \sigma}\right)\left(1-\frac{1}{\sigma}\right)^{-1}
$$

with $\sigma>1$ to make sure that an estate taxes $\tau^{x}$ has a depressive effect on $x$. Isoelasticity implies homotheticity, a property that we shall use below. Labor supply in the first period is inelastic. One shows that

$$
d_{t+1}=\delta\left(1+r_{t+1}\right) \tilde{s}\left(r_{t+1}\right)\left(w_{t}+h_{t}\right)
$$

27 This section follows Michel and Pestieau (2002) and Pestieau and Sato (2008). On this subject, see also Blumkin and Sadka (2004). 
and

$$
(1+n) x_{t+1}\left(1+\tau_{t}^{x}\right)=(1-\delta)\left(1+r_{t+1}\right) \tilde{s}\left(r_{t+1}\right)\left(w_{t}+h_{t}\right)
$$

where $h_{t}$ is inherited wealth, with

$$
h_{t}=x_{t}+\left(\frac{1-\theta}{1+n}\right)\left(1+\tau_{t}^{\theta}\right) d_{t}+R_{t},
$$

while $\delta$ is the share of saving devoted to second period consumption, $\tilde{s}(r)$ is the saving ratio, $\tau^{x}$ and $\tau^{\theta}$ are respectively the tax on voluntary and accidental bequests, respectively, and $R_{t}$ is a uniform lump-sum payment financed by wealth transfer taxes. Clearly if $\gamma=0,(\delta=1)$ there is no intended bequest. If $\theta=1$, (longevity is certain) there is no accidental bequests. In this approach inherited wealth varies across individuals. It depends on one's parent's intended bequest $x_{t}$, second period consumption $d_{t}$ and longevity $\theta_{t}$. At each period, the revenue constraint is simply:

$$
R_{t}=\frac{\left(1+r_{t}\right) \bar{s}_{t-1}}{1+n}\left(\frac{\tau_{t}^{x}(1-\delta)}{1+\tau_{t}^{x}}+\delta \tau_{t}^{\theta}(1-\theta)\right)
$$

where the upper-bar denotes average values. If the social planner's objective is to minimize the steady-state coefficient of variation of inherited wealth, one can easily show that $\tau^{\theta}=1$ and $\tau^{x}$ is likely to be between 0 and 1 for $\sigma \geq 1$. Note that here $R_{t}$ is not a fixed amount of public spending but an endogenous lump-sum transfer. In the normal case when one cannot distinguish bequest motives and there is a single rate of taxation $\tau^{\theta}=\frac{\tau^{x}}{1+\tau^{x}}$ then one shows that the optimal value of this unique rate represents a compromise between the equity objective and the desire of not discouraging wealth accumulation. The closer $\delta$ is to 1 , the closer the tax to 1 .

In this very simple model the only source of inequality is longevity $\theta$. When $\theta=1$ or when $\tau^{\theta}=1$, then there is no inequality. Introducing a second source of heterogeneity, e.g., different productivities, is surely more realistic. In that case, as shown by Blumkin and Sadka (2004) even when there is only accidental bequest a $100 \%$ tax is not necessarily desirable.

\subsubsection{Altruists and life-cyclers}

For long economists have rejected the idea of heterogeneous preferences. Differences in behavior had to be explained by differences in ability, inherited wealth or by random shocks. Over the last years, there is an increasing awareness that to better understand the world and analyze economic policy it is important to admit that society consists of 
individuals with different preferences in terms of altruism and time preference. In his celebrated paper, Ramsey (1928) already indicated that within a society consisting of individuals differing in time preferences, the most patient would end up with all the wealth in the long run.

In this section, we address the question of wealth transfer tax in a society with two types of individuals, pure life-cyclers and altruistic savers. ${ }^{28}$ Formally, their utility function is:

$$
u_{t}^{i}=u\left(c_{t}^{i}, d_{t+1}^{i}\right)+\gamma^{i} u_{t+1}^{i}
$$

with $i=L$ for life-cyclers and thus $\gamma^{L}=0$ and $i=A$ for altruists and thus $\gamma^{A}=\gamma>0$. The technology is the same as above: CRS production function and we have competitive profit maximization. Population grows at a uniform rate $n$ and preferences are dynastic. In other words, there is a fixed fraction $\pi$ of altruistic dynasties and a fraction $1-\pi$ of non-altruistic dynasties.

It can easily be shown that government debt does not affect the steady-state capital stock and national income. As in Ramsey, the altruistic (the more patient) households hold the entire capital stock. Moreover, government debt though neutral in aggregate terms increases steady-state inequality. A higher level of debt means a higher level of taxation to pay for the interest payments. The taxes fall on both life-cyclers and altruists but the interest payments go entirely to the altruist. Consequently, a higher level of debt, or alternatively of pay-as-you-go social security, raises the steady-state consumption and income of the altruists and lower the steady-state consumption and income of the life-cyclers.

For the purpose at hand we are interested by the incidence of a wealth transfer tax which in the present setting is only paid by altruistic dynasties. Assuming that the proceeds of the tax are redistributed uniformly to everyone, it can be shown that the tax may lower the utility of not only the altruists but also that of the life-cyclers. This paradoxical result was already obtained by Stiglitz (1978) in a slightly different setting. ${ }^{29}$ When capital is taxed the quantity falls which in turns depresses the real wage. This effect may be large enough to make any tax on wealth transfer undesirable even from the standpoint of people who own no wealth, pay no tax and indeed benefit from a transfer.

One should recall that this result is obtained in the steady-state. In the short run life-cyclers could be tempted to tax inheritance and enjoy a utility boost. If they have to vote they will vote for such a tax without being concerned by the fate of their descendance. The political economy of

\footnotetext{
28 See Michel and Pestieau (1998, 1999, 2000, 2005).

29 See also Stiglitz (1977).
} 
wealth transfer thus yields a result different from steady-state social welfare maximization. It explains why a tax that would be undesirable from the steady-state standpoint can be voted on when life-cyclers hold a majority.

One of the problems with segmenting population in spenders and savers is that it does not reflect the fact that top wealth is not alway held by altruistic parents but rather by individuals who have a strong preference for wealth without bequest motives. Pestieau and Thibault (2011 in press) study the case of a society with individuals differing in their degree of altruism and their preference for wealth. They reach results that depend on the type of equilibrium obtained. In the equilibrium in which only those with wealth preference are holding wealth an estate tax is shown to increase the welfare of everyone.

\subsection{Unobservability of inherited wealth}

Regardless of the type of wealth transfer taxation, inheritance or estate tax, its actual yield is uniformly poor. It is clear that such taxes are not successful, if their primary objective has been to reduce reliance on other taxes. This poor yields have led some countries to seriously consider abandoning the tax. In any case, from a theoretical viewpoint, it is interesting to see how other taxes should be adjusted if wealth transfers could not be taxed anymore.

Boadway et al. (2000) and Cremer et al. (2001, 2003) have addressed the question of the optimal taxation of labor and interest income in an economy where not only ability but also inheritance were not observed. ${ }^{30}$ In such a setting, even with separability between leisure and consumption, Atkinson and Stiglitz proposition does not apply and there is a good case for taxing capital income. ${ }^{31}$ Intuitively, the additional instrument of capital income taxation now improves screening for the unobservable characteristics. Roughly speaking its role is to indirectly tax inherited wealth.

This brings us back to the old public finance debate between a comprehensive income tax and an expenditure tax. For the latter to be desirable one needs to be sure that inheritance can be effectively taxed. When this is not possible, one must rely on an income tax which involves double taxation of capital income.

\footnotetext{
30 As a matter of fact, one only needs to assume that a fraction of inherited wealth cannot be observed. In this quite realistic case, the same results hold true.

31 Because of the two-dimensional heterogeneity, a tax on capital income is an effective way of relaxing an otherwise binding self-selection constraint. This is because even under seperability, mimicker and mimicking individual do not have the same marginal rate of substitution between first and second period consumption.
} 


\subsection{Investment in the human capital of children}

In most societies there are two main ways of transferring financial resources to one's children: human and physical capital. Human capital indeed represents a large share of voluntary intergenerational transfers in most families, except the very rich.

As argued by Becker and Tomes $(1979,1986)$, parents tend to devote resources on behalf of their children, first to education and then to physical bequest. We are not thinking of time and attention but of financial spending. Becker and Tomes consider two transfers: $e$ for education and $x \geq 0$ for bequest. The overall transfer is $e+x$ whereas inherited resources are $w h(e)+(1+r) x$ where $h$ is the (strictly concave) human capital function and $r$ the rate of interest. Accordingly parents have to devote their saving to their own second period consumption, to $e$ ant to $x$. Take a simple two period model; their utility function is

$$
u(c, d, w h+x)=u\left(w h(\bar{e})-s,(1+r) s-e-\frac{x}{1+r}, w h(e)+(1+r) x\right)
$$

where $\overline{\mathrm{e}}, w$ and $r$ are given and the bequest motive is an extended form of joy of giving. Parents are concerned by the life-cycle income of their only child. ${ }^{32}$ There are two possible types of solution to this problem. For some individuals: $x=0$ and $e<e^{*}$ where $e^{*}$ is defined by: $w h^{\prime}\left(e^{*}\right)=1+r$. These individuals would like to finance high educational expenditures through a negative bequest which is not possible. Hence, the non-negativity constraint on $x$ is binding. For others $e=e^{*}$ and $x>0$. Whether parents are constrained by the assumption that $x \geq 0$ and thus leave $0 \leq e<e^{*}$ depends on their wealth, their degree of (imperfect) altruism and on the relative returns of both types of transfers $\left(r\right.$ versus $\left.w h^{\prime}(e)\right)$.

The question at hand is whether these two types of transfer ought to be taxed (or subsidized) differently. Even in the simple framework adopted here both types have different economic implications. For pure efficiency reason there is a good case for subsidizing $e$ up to the level $e^{*}$ even if this requires taxing financial bequests. Furthermore in a dynamic setting of endogenous growth a number of papers have more or less explicitly shown that education ought to be subsidized and/or supplied collectively. This holds particular true when an optimal income tax is available. See Glomm and Ravikunar (1992), Benabou (2002).

Cremer and Pestieau (2006a, 2006b) consider a model of successive generations wherein parents provide education out of some joy of giving and with the knowledge that it increases the probability that their child(ren)

32 We have $n=0$. 
will be highly productive. Individual are only differentiated by their degree of productivity. The paper shows that when a non-linear income tax is available and when there is no laundering, there is a good case for subsidizing private education and possibly for providing some public education. $^{33}$

\section{Conclusion}

Even though our survey is limited to the normative aspects of wealth transfer taxation there are a number of questions that we have not dealt with. There is particularly the question why estate taxation is today so unpopular that in some countries the political system is considering abolishing it.

There is first the issue of avoidance and evasion which not only leads to poor tax yields but also leads to strong departure from both vertical and horizontal equality. Related to that, there is the issue of tax competition within countries and among countries. In federal states one observes a real race to the bottom regarding estate taxation. In an economic union such as the European one there is an increasing tax competition for financial wealth and this includes estate taxation. Another issue pertains to alleged adverse effect of estate taxation on family businesses.

Those three issues have a real political impact and yet there is little evidence on how important is their effect. It is thus not surprising that there exists little theoretical work taking them into account.

\section{Acknowledgements}

We are grateful to Ravi Kanbur, Sandro Cigno and Serge Christophe Kolm for suggestions.

\section{References}

Aaron, H.J. and A.H. Munnell (1992), "Reassessing the Role for Wealth Transfer Taxes", National Tax Journal 45, 119-143.

Abel, A.B. (1985), "Precautionary Saving and Accidental Bequests", American Economic Review 75, 777-791. 33 Grossmann and Poutvaara (2009) show that bequest taxation may improve efficiency
when combined with wage taxation. 
Altonji, J.G., F. Hayashi and L.J. Kotlikoff (1992), "Is the Extended Family Altruistically Linked? Direct Tests using Micro Data", American Economic Review 105, 1121-1166.

Andreoni, J. (1990), “Impure Altruism and Donations to Public Goods: a Theory of Warm-Glow Giving?", Economic Journal 100, 464-477.

Arrondel, L., A. Masson and P. Pestieau (1997), "Bequests and Inheritance: Empirical Issues and French-US Comparison", in G. Erreygers and T. Vandevelde, eds., Is Inheritance Legitimate? Ethical and Economic Aspects of Wealth Transfers, Springer, Berlin, pp. 89-125.

Atkinson, A.B. and A. Sandmo (1980), "Welfare Implications of the Taxation of Savings", Economic Journal 90, 529-549.

Atkinson, A.B. and J.E. Stiglitz (1972), "The Structure of Indirect Taxation and Economic Efficiency", Journal of Public Economics 1, 97-119.

Atkinson, A.B. and J.E. Stiglitz (1976), "The Design of Tax Structure: Direct Versus Indirect Taxation", Journal of Public Economics 6, 55-75.

Atkinson, A.B. and J.E. Stiglitz (1980), Lectures in Public Economics, McGraw Hill, New York.

Banks, J. and P. Diamond (2010), "The Base for Direct Taxation", in Insitute of Fiscal Studies, eds., Dimensions of Tax Design. The Mirrlees Review, Oxford University Press, Oxford, pp. 548-674.

Batina, R. and T. Ihori (2000), Consumption Tax Policy and the Taxation of Capital Income, Oxford University Press, Oxford.

Barro, R. (1974), “Are Government Bonds Net Wealth?”, Journal of Political Economy 82, 1095-1117.

Becker, G.S. and N. Tomes (1979), "An Equilibrium Theory of the Distribution of Income and Intergenerational Mobility", Journal of Political Economy 87, 1153-1189.

Becker, G.S. and N. Tomes (1986), "Human Capital and the Rise and Fall of Families", Journal of Labor Economics 4, S1-S39.

Benabou, R. (2002), “Tax and Education Policy in an Heterogenous Agent Economy: What Levels of Redistribution Maximize Growth and Efficiency?", Econometrica 70, 481-517.

Bernheim, B.D., A. Shleifer and L.H. Summers (1985), "The Strategic Bequest Motive", Journal of Political Economy 93, 1045-1076.

Bevan, D.L. and J.E. Stiglitz (1979), "Intergenerational Transfers and Inequality", Greek Economic Review 1, 8-26.

Blumkin, T. and E. Sadka (2004), "Estate Taxation”, Journal of Public Economics 88, 1-21. 
Boadway, R., M. Marchand and P. Pestieau (2000), "Redistribution with Unobservable Bequests: a Case for Capital Income Tax", Scandinavian Journal of Economics 102, 1-15.

Boadway, R., E. Chamberlain and C. Emmerson (2010), "Taxation of Wealth and Wealth Transfers", in Insitute of Fiscal Studies, eds., Dimensions of Tax Design. The Mirrlees Review, Oxford University Press, Oxford, pp. 737-814.

Brenner, G.A. (1985), “Why did Inheritance Laws Change?”, International Review of Law and Economics 5, 91-106.

Chamley, C. (1986), “Optimal Taxation of Capital Income in General Equilibrium with Infinite Lives”, Economica 54, 607-622.

Cigno, S. (1991), Economics of the Family, Oxford University Press, Oxford.

Coleman, W.J. (2000), "Welfare and Optimum Dynamic Taxation of Consumption and Income", Journal of Public Economic 76, 1-39.

Cox, D. (1987), "Motives for Private Income Transfers", Journal of Political Economy 95, 508-546.

Cremer, H. and P. Pestieau (1988), "A Case for Differential Inheritance Taxation", Annales d'Economie et de Statistiques 9, 167-182.

Cremer, H. and P. Pestieau (1991), "Bequest, Filial Attention and Fertility", Economica 58, 359-375.

Cremer, H. and P. Pestieau (1996), "Bequests as a Heir "Discipline Device", Journal of Population Economics 9, 405-414.

Cremer, H. and P. Pestieau (1998), "Delaying Inter Vivos Transmission under Asymmetric Information", Southern Economic Journal 65, 322-331.

Cremer, H. and P. Pestieau (2001), "Non-linear Taxation of Bequests, Equal Sharing Rules and The Trade-off Between Intra- and Inter-Family Inequalities", Journal of Public Economics 79, 35-54.

Cremer, H. and P. Pestieau (2006a), "Intergenerational Transfer of Human Capital and Optimal Income Taxation”, Journal of Public Economic Theory 8, 529-545.

Cremer, H. and P. Pestieau (2006b), "Wealth Transfer Taxation: a Survey of the Theoretical Literature", in S.C. Kolm and J. Mercier Ythier, eds., Handbook on Altruism, Giving and Reciprocity, vol. 2, North Holland, Amsterdam, pp. 1108-1134.

Cremer, H., D. Kessler and P. Pestieau (1993), "Education for Attention: a Nash Bargaining Solution to the Bequest-as-Exchange Model", Public Finance 48, 85-97. 
Cremer, H., P. Pestieau and J.-C. Rochet (2001), "Direct Versus Indirect Taxation: the Design of the Tax Structure Revisited", International Economic Review 42, 781-799.

Cremer, H., P. Pestieau and J.-C. Rochet (2003), "Capital Income Taxation when Inherited Wealth is not Observable", Journal of Public Economics 87, 2475-2490.

Davies, J.B. (1981), "Uncertain Lifetime, Consumption and Dissaving in Retirement", Journal of Political Economy 89, 561-577.

Diamond, P. (1965), "National Debt in a Neoclassical Growth Model", American Economic Review 58, 1126-1150.

Diamond, P. (2006), "Comment on M. Golosov, A. Tsyvinski, I. Werning, New Dynamic Public Finance: A User's Guide", NBER Macroeconomics Annual 2006, 365-379.

Erregeyers, G. and T. Vandevelde (1997), Is Inheritance Legitimate? Ethical and Economic Aspects of Wealth Transfers, Springer, Berlin.

Gale, W.G., J.R. Hines and J. Slemrod (eds.) (2000), Rethinking Estate and Gift Taxation, Brookings Institution, Washington DC.

Glomm, G. and R. Ravikunar (1992), "Public Versus Private Investment in Human Capital: Endogenous Growth and Income Inequality", Journal of Political Economy 100, 818-834.

Golosov, M., A. Tsyvinski and I. Werning (2007), "New Dynamic Public Finance: A User's Guide", NBER Macroeconomics Annual 2006, 317-363.

Grossmann, V. and P. Poutvaara (2009), "Pareto-Improving Bequest Taxation", International Tax and Public Finance 16, 647-669.

Hammond, P. (1988), "Altruism", in J. Eatwell, M. Milgate and P. Newman, eds., New Palgrave: a Dictionary of Economics, Macmillan Press, London, pp. 85-87.

Harsanyi, J. (1995), "A Theory of Social Values and a Rule Utilitarian Theory of Morality", Social Choice and Welfare 12, 319-344.

Judd, K.L. (1985), "Redistributive Taxation in a Simple Perfect Foresight Model", Journal of Public Economics 28, 59-83.

Kaplow, L. (2000), "A Framework for Assessing Estate and Gift Taxation", in W.G. Gale, J.R. Hines and J. Slemrod, eds., Rethinking Estate and Gift Taxation, Brookings Institution, Washington DC.

Kopczuk, W. (2001), "Optimal Estate Taxation in the Steady-State", unpublished.

Kopczuk, W. (2003), "The Trick is to Live. Is the Estate Tax Social Security for the Rich?", Journal of Political Economy 111, 1318-1341. 
Kotlikoff, L.J. and A. Spivak (1981), "The Family as an Incomplete Annuities Market”, Journal of Political Economy 89, 372-391.

Masson, A. and P. Pestieau (1997), "Bequests Motives and Models of Inheritance: a Survey of the Literature", in G. Erreygers and T. Vandevelde, eds., Is Inheritance Justified?, Springer, Berlin, pp. 54-88.

Michel, P. and P. Pestieau (1998), "Fiscal Policy in a Growth Model with both Altruistic and Non-Altruistic Agents", Southern Economic Journal 64, 682-697.

Michel, P. and P. Pestieau (1999), "Fiscal Policy in a Growth Model where Individuals Differ with Regard to Altruism and Labor Supply", Journal of Public Economic Theory 1, 187-203.

Michel, P. and P. Pestieau (2000), "Tax-Transfer Policy with Altruists and Non-altruists", in L.A. Gérard-Varet, S.C. Kolm and J. Mercier Ythier, eds., The Economics of Reciprocity, Giving and Altruism, Macmillan, International Economic Association, London, pp. 275-284.

Michel, P. and P. Pestieau (2002), "Wealth Transfer Taxation with both Accidental and Desired Bequests", unpublished.

Michel, P. and P. Pestieau (2005), "Fiscal Policy with Agents Differing in Altruism and in Ability", Economica 72, 121-136.

Pestieau, P. (1974), "Optimal Taxation and Discount Rate for Public Investment in a Growth Setting", Journal of Public Economics 3, 217-235.

Pestieau, P. (2000), “Gifts, Wills and Inheritance Law”, in B. Bouckaert and G. De Geest, eds., Encyclopedia of Law and Economics, vol. 3, Edward Edgar, Northampton, MA, pp. 888-906.

Pestieau, P. (2003), "The Role of Gift and Estate Transfers in the United States and in Europe", in A. Munnell and A. Sunden, eds., Death and Dollars, The Brookings Institution Press, Washington DC, pp. 64-85.

Pestieau, P. and M. Sato (2008), "Estate Taxation with both Accidental and Planned Bequests", Asia-Pacific Journal of Accounting and Economics (APJAE) 15, 223-240.

Pestieau, P. and E. Thibault (2011), "Love thy Children or Money Reflections on Debt Neutrality and Estate Taxation", Economic Theory (forthcoming).

Ramsey, F.P. (1928), "A Mathematical Theory of Saving”, Economic Journal 38, 543-559.

Rosenthal, P.A. (1991), “Pratiques Successorales et Fécondité”, Economie et Prévision, 100-101, 231-238. 
Saez, E. (2002), "Optimal Progressive Capital Income Taxes in the Infinite Horizon Model", NBER Working Paper No. 9046.

Smith, R.S. (2001), "Personal Wealth Taxation and the European Union", University of Alberta, unpublished.

Stiglitz, J.E. (1977), "Equality, Taxation and Inheritance", in W. Krelle and A. Shorrocks, eds., Personal Income Distribution, North-Holland, Amsterdam, pp. 271-303.

Stiglitz, J.E. (1978), "Notes on Estate Taxes, Redistribution and the Concept of Balanced Growth Path Incidence", Journal of Political Economy 86, 137-150.

Stiglitz, J.E. (1987), "Pareto Efficient and Optimal Taxation in the New Welfare Economics", in A.J. Auerbach and M. Feldstein, eds., Handbook of Public Economics, vol. 2, North-Holland, Amsterdam, pp. 991-1042. 